\title{
Model fit and reliability of the Hungarian version of the Revised Exercise Addiction Inventory (EAI-R-HU)
}

\author{
ATTILA SZABO ${ }^{1,2}$ \\ ${ }^{1}$ Institute of Health Promotion and Sport Sciences, ELTE Eötvös Loránd University, \\ Budapest, Hungary \\ ${ }^{2}$ Institute of Psychology, ELTE Eötvös Loránd University, Budapest, Hungary
}

(Received: 16 April 2021, accepted: 9 July 2021)

The Exercise Addiction Inventory (EAI) is a brief validated instrument adopted by many to assess the risk of exercise addiction. Its revised version (the EAI-R) has been recently validated in English with a predominantly male sample. The current work examined the model fit, validity and reliability of the Hungarian version of the EAI-R (EAI-R-HU). This cross-sectional study was conducted online. A convenience sample of regular exercisers $(n=253)$ completed the EAI-R-HU and answered demographic questions. Confirmatory factor analysis revealed a good model fit for the Hungarian version of the instrument. The internal reliability of the EAI-R-HU was (Cronbach's $\alpha$ ) .71. Considering the top 20\% of the EAI-R-HU scores, $5.1 \%$ of the sample was at risk of exercise addiction. Team exercisers did not differ from individual exercisers in the risk of exercise addiction. Age and exercise characteristics predicted weakly but statistically significantly the risk of exercise addiction. The EAI-R-HU possesses a good model fit, and its internal reliability is acceptable. These findings complement the original revision of the EAI-R, based on a largely $(87.7 \%)$ male sample compared to the current research primarily based on female participants $(76.7 \%)$. While cultural differences might exist, the present results encourage the use of the EAI-R with women too and with Hungarian samples, in general.

Keywords: behavioral addiction, exercise, exercise addiction, psychometrics, questionnaire development

\section{Introduction}

Scholars believe that exercise addiction is a mental dysfunction that surfaces when people lose control over their exercise behavior (Szabo, 2010). These individuals manifest severe withdrawal symptoms when exercise is prevented and could experience inter- and intrapersonal conflict and harmful life consequences stemming from their exaggerated exercise involve-

\footnotetext{
* Correspondence: Prof. Attila Szabo, Ph.D., D.Sc., Institute of Health Promotion and Sports Sciences, Faculty of Education and Psychology, ELTE Eötvös Loránd University, H-1117 Budapest, Bogdánfy u. 10, Hungary. E-mail: szabo.attila@ppk.elte.hu
} 
ment (Szabo, Griffiths, De La Vega Marcos, Mervó, \& Demetrovics, 2015). Although there may be over 1000 publications in the area of exercise addiction (Szabo \& Kovacsik, 2019), there are no diagnosed cases of exercise addiction because there are no clinical diagnostic criteria for it. While some scholars classify overexercising as a behavioral addiction (Egorov \& Szabo, 2013), exercise addiction is not included in the latest edition of the Diagnostic and Statistical Manual of Mental Disorders (DSM-5; American Psychiatric Association, 2013).

In the assessment of exercise addiction, most researchers still use the DSM criteria for substance abuse (Hausenblas \& Downs, 2002) or the Components Model of addiction (Griffiths, 2005) as the theoretical underpinning of their work. Griffiths' Components Model comprises six common symptoms of addictions (salience, conflict, mood modification, withdrawal, tolerance, and relapse), regardless of whether they are chemical- or behaviorrelated. These symptoms are determined with the Exercise Addiction Inventory (EAI; Terry, Szabo, \& Griffiths, 2004; Griffiths, Szabo, \& Terry, 2005), which is a widely used instrument in research assessing the risk of exercise addiction. This tool was used in over 100 published studies, and it was adopted in several different languages (Szabo, Pinto, Griffiths, Kovacsik, \& Demetrovics, 2019).

The EAI was translated into the Hungarian language too (Demetrovics \& Kurimay, 2008), and it was employed in several studies, but its factor structure and model fit were not evaluated in the original publication. However, later, a population-wide study (Mónok et al., 2012) and a crosscultural examination of the EAI (Griffiths et al., 2015) have revealed that the Hungarian version of the original EAI has a good model fit. Recently, the original version of the instrument was revised. Although the items' text did not change, the spectrum of the rating scale was increased from five to six points. The argument for the change was that the 5-point scale has a neutral middle point that could artificially raise the total score and, hence, the interpretation of the results. The original EAI has five Likert-scale rating categories: strongly disagree, disagree, neither disagree nor agree, agree, and strongly agree. The middle item (neither agree nor disagree), scored as 3 , reflected a neutral answer but added to the total score and increased the estimation of the risk of exercise addiction (Szabo et al., 2019). Thus, by changing the rating scale's range from five to six points, such as: strongly disagree, disagree, slightly disagree, slightly agree, agree, and strongly agree, one can obtain two general categories of answers, one reflecting agreement and the other disagreement. These pillar categories could then be reduced to two (such as yes or no) if there is a practical need for it (Allen \& Seaman, 2007).

The EAI's original version (Terry et al., 2004) comes with good psychometric properties. Its factor loadings range from .610 to .801 . Its concurrent validity with the Exercise Dependence Scale (Hausenblas \& Downs, 2002) 
was demonstrated in a population-wide study (Mónok et al., 2012). Its content and construct validity were also shown (Terry et al., 2004), and its two-week test-retest reliability was good ( $r=.85$; Griffiths et al., 2005). The internal reliability of the EAI was (Cronbach's $\alpha$ ) .84 in the developers' original study (Terry et al., 2004). However, in a cross-cultural investigation, it only ranged from .61 to .80 , while that of the Hungarian version was .61 and .73 in two studies, respectively (Griffiths et al., 2015). The internal reliability of the modified EAI-R is higher than that of the original version $(\alpha=.90)$. The authors (Szabo et al., 2019) recommend a shift in using the revised EAI (EAI-R) instead of the original EAI. Consequently, its reliability should be evaluated in several other languages, including Hungarian. Therefore, this cross-sectional study aimed to test the model fit, validity, and reliability of the EAI-R in Hungarian. Based on the findings of Szabo and colleagues (2019), which indicated that the EAI-R has better psychometric properties than the original EAI (Terry et al., 2004), it was hypothesized that the Hungarian version of the EAI-R would also demonstrate better model fit and reliability than its earlier validated version (Griffiths et al., 2015; Mónok et al., 2012).

\section{Methods}

\subsection{Participants}

Ethical permission for the study was obtained from the Research Ethics Committee of the Faculty of Education and Psychology at ELTE Eötvös Loránd University (permission number: 2015/220). The participants' recruitment took place on Facebook, and it was complemented by the snowball method (Goodman, 1961). A total of 368 respondents completed the research on the Qualtrics platform between September and October 2019. Non-exercisers, participants who completed the study in less than a minimum reasonable time or provided incomplete answers were excluded from the study. The final sample comprised 253 regularly exercising participants; most were women $(n=194,76.7 \%)$. Their age ranged from 18 to 77 years, and they performed over 30 different forms of individual or group exercises. Apart from gender, age, and exercise habits, volunteers were asked no other personal questions.

\subsection{Materials}

Demographic questions asked the participants their age, gender, and exercise habits (Table 1). The latter involved: 1) the weekly frequency of exercise on a 7-point categorical scale ranging from at least one to more than 
ten exercise occasions per week, 2) the estimated average duration of an exercise session (minutes) on a 5-point Likert scale, ranging from at least thirty minutes to more than 120 minutes per exercise occasion, and 3) the subjectively appraised average intensity of the usual exercise sessions, rated on the Borg CR-10 scale (Borg, 1985), that ranges from 0 to 10, where a score of 0 reflects extremely low intensity exercise and a score of 10 represents extremely high intensity exercise.

The Exercise Addiction Inventory-Revised (EAI-R; Szabo et al., 2019) was used to measure the risk of exercise addiction. This modified scale's items (EAI-R-HU) are identical to the original EAI (Terry et al., 2004). The six statements of the EAI-R reflect Griffiths' (2005) Components Model of addictions. They gauge six common symptoms of addictions initially rated on a 5-point Likert scale, modified by Szabo and colleagues (2019) into a 6-point scale in the new EAI-R (1 = strongly disagree; 2 = disagree, 3 = slightly disagree, $4=$ slightly agree, $5=$ agree, and $6=$ strongly agree). In the current work, the text of the validated Hungarian version of the EAI (Mónok et al., 2012) was used, with the only change that the 5 point rating scale was expanded to 6 points, as done with the earlier English version of the EAI-R (Szabo et al., 2019). The EAI-R-HU is presented in the Appendix. Scores in the top fifth (or above $80 \%$ ) of the range of the scores, corresponding to a value above 28.8 out of the maximum score of 36 , is considered to reflect the risk of exercise addiction.

\subsection{Procedure}

The respondents participated in the study by anonymously completing the questionnaires on the Qualtrics research platform (Qualtrics, 2017), having a unique Uniform Resource Locator (URL) for the current study. Before accessing the questionnaires, volunteers had to read a consent form and agree to participation by selecting an "I agree" button. Only those with fully completed $(100 \%)$ answers were included in the current study. Data were exported in a Statistical Package for Social Sciences (SPPS v. 26) file, and the calculations were done with the same software.

\subsection{Statistical analyses}

Gender differences in exercise habits and risk of exercise addiction were tested with multivariate analysis of variance (MANOVA). The model fit of the EAI-R-HU was tested with confirmatory factor analysis (CFA). Discriminant validity of the EAI-R-HU was calculated with analysis of covariance (ANCOVA). Reliability was based on Cronbach's alpha. Differences in the risk of exercise addiction between team and individual exercisers were 
compared with analyses of variance (ANOVA). Differences in exercise characteristics of those at risk of exercise addiction and not at risk were compared with Mann-Whitney $U$ tests to account for the large difference in the size of the two groups. Pearson's $r$ correlations were performed to examine the relationship between age and exercise parameters. Hierarchical linear regression was performed to examine the predictors of the level of the risk of exercise addiction, or EAI-R-HU scores.

\section{Results}

\subsection{Gender differences}

First, gender differences were tested with multivariate analysis of variance (MANOVA) using age, exercise frequency, duration, intensity, and EAI-RHU total scores as dependent measures. This test revealed that women scored lower than men in three exercise characteristics (Table 1) but not in the EAI-R-HU scores. Further, the nonparametric chi-square tests indicated that the frequency of the risk of exercise addiction was not different between the two genders. Finally, the proportion of individual and group-exercisers in the sample was also statistically not significantly different between men and women (Table 1).

Table 1. Participants' characteristics categorized by gender

\begin{tabular}{|c|c|c|c|}
\hline Variables & $\begin{array}{c}\text { Men } \\
(n=59)\end{array}$ & $\begin{array}{l}\text { Women } \\
(n=194)\end{array}$ & $\begin{array}{c}\text { Significance } \\
\text { level } \\
(F[1,251], p)^{\text {a }}\end{array}$ \\
\hline & $M(\mathrm{SD})$ & $M(\mathrm{SD})$ & \\
\hline Age & $37.22(14.20)$ & $36.22(14.65)$ & $0.22, .643$ \\
\hline Weekly frequency of exercise & $3.61(1.70)$ & $3.16(1.49)$ & $3.86, .050$ \\
\hline $\begin{array}{l}\text { Estimated average duration } \\
\text { of an exercise session (minutes) }\end{array}$ & $82.88(23.20)$ & $71.91(25.59)$ & $8.68, .004$ \\
\hline $\begin{array}{l}\text { Estimated average intensity } \\
\text { of the exercise sessions } \\
\text { (11-point scale) }\end{array}$ & $6.73(1.66)$ & $5.91(1.63)$ & $13.01, .001$ \\
\hline \multirow[t]{2}{*}{ Total score on the EAI-R-HU } & $19.78(5.26)$ & $20.04(5.50)$ & $0.10, .747$ \\
\hline & Percentages & Percentages & $\left(\chi^{2}[1], p\right)^{\mathrm{b}}$ \\
\hline $\begin{array}{l}\text { Proportion of those at risk and } \\
\text { not at risk of exercise } \\
\text { addiction }\end{array}$ & $\begin{array}{c}3.39 \% \text { at risk; } \\
96.61 \% \text { not at risk }\end{array}$ & $\begin{array}{c}5.67 \% \text { at risk; } \\
94.33 \% \text { not at risk }\end{array}$ & $0.48, .487$ \\
\hline $\begin{array}{l}\text { Proportion of those exercising } \\
\text { alone and in group }\end{array}$ & $\begin{array}{c}45.8 \% \text { alone, } \\
54.20 \% \text { in group }\end{array}$ & $\begin{array}{c}49.00 \% \text { alone, } \\
51.00 \% \text { in group }\end{array}$ & $0.19, .666^{\mathrm{b}}$ \\
\hline
\end{tabular}

Note: superscripts ${ }^{\mathrm{a}}=$ based on MANOVA; ${ }^{\mathrm{b}}=$ based on Chi Square test. 


\subsection{Model fit of the EAI-R-HU}

In testing the model fit, the data were subjected to confirmatory factor analysis (CFA) to examine whether they conform to the original model (Szabo et al., 2019). For model fit, a non-significant likelihood ratio (chisquare) test, TLI (Tucker Lewis Index) cutoff value >.95, CFI (Comparative Fit Index) cutoff value >.95, RMSEA (Root Mean Square Error of Approximation) cutoff value $<.06$, and SRMR (Standardized Root Mean Square Residual) cutoff value $<.08$ were used as the suggested criteria ( $\mathrm{Hu} \&$ Bentler, 1999; Shi, Lee, \& Maydeu-Olivares, 2019). Kline (2015) recommends that in CFA, a minimum of four indices should be reported:1) the model chi-square, 2) RMSEA, 3) CFI, and 4) SRMR. However, we also report the TLI cutoff $>.95$ because it is less sensitive in sample size over 100 (Taasoobshirazi \& Wang, 2016), as well as the Goodness of Fit Index (GFI) cutoff value $>.90$ (Baumgartner \& Homburg, 1996), to compare it to the value reported for the EAI-R (Szabo et al., 2019). The results of the CFA yielded excellent fit indices. The factor loadings were all $>.40$ and the $R^{2}>.20$, except in item 2 (conflict) in which the $R^{2}$ was .18 (Figure 1). Consequently, the CFA yielded excellent model fit and acceptable factor loadings. Still, one item contributed only little (18\%) to the shared variance. Given that the original EAI-R was validated in a largely $(87.7 \%)$ male sample (Szabo et al., 2019), and that gender differences in its interpretation might exist (Griffiths et al., 2015), the CFA calculation separately for men and women was deemed useful in gathering additional information about the construct validity of the scale. Table 2 summarizes the results of the CFA for the whole sample and separately for men $(n=59)$ and women $(n=194)$, which also yielded good model fits. Only one index of model fit, the TLI, did not reach the recommended cutoff value in the men's sample.

Table 2. Model fit of the EAI-R-HU in the whole sample and separately for men and women

\begin{tabular}{|l|c|c|c|c|c|c|c|c|}
\hline & CMIN & $d f$ & $p$ & GFI & RMSEA (90\% CI) & CFI & TLI & SRMR \\
\hline Sample $(n=253)$ & 9.67 & 9 & .38 & .987 & $.017(.001-.074)$ & .997 & .995 & .030 \\
\hline Men $(n=59)$ & 10.49 & 9 & .31 & .941 & $.053(.001-.163)$ & .963 & .939 & .079 \\
\hline Women $(n=194)$ & 11.14 & 9 & .27 & .981 & $.035(.001-.093)$ & .990 & .983 & .035 \\
\hline
\end{tabular}

Note: In all cases the CMIN/DF was $<5.0$ and PCLOSE was $>1.0$. 


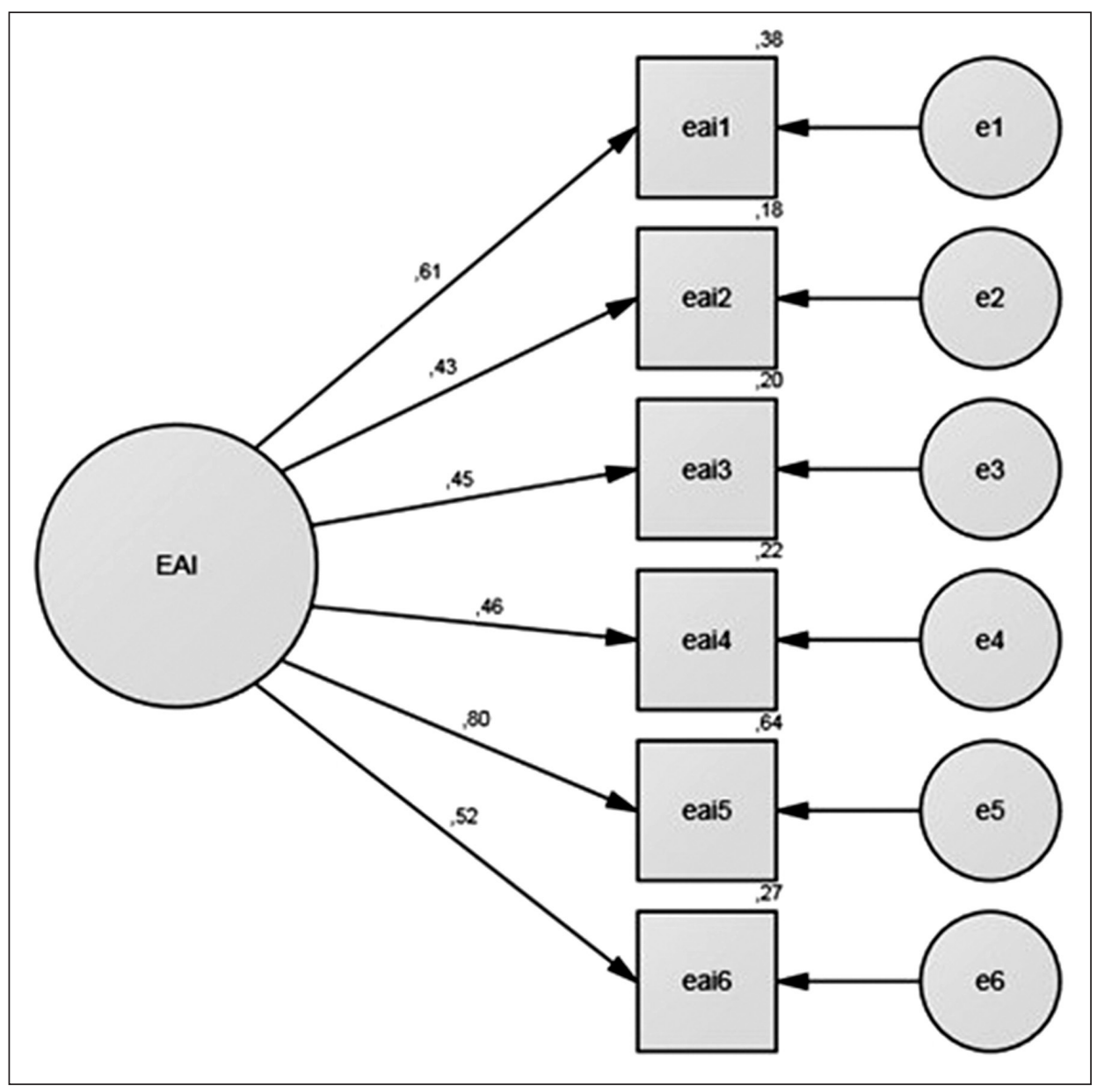

Figure 1. Confirmatory factor analysis model showing the factor loadings and $R^{2}$ values

\subsection{Reliability}

The internal reliability of the EAI-R-HU in the whole sample was $($ Cronbach's $\alpha)=.71$. When determined separately for men and women, it was relatively weak for men (.62) and acceptable for women (.74). The splithalf correlation of the EAI-R-HU, using Spearman-Brown correction (Frey, 2018) was .732, and the Guttman split-half coefficient was .727. 


\subsection{Discriminant validity}

The discriminant validity of the EAI-R-HU was tested with a univariate analysis of covariance (ANCOVA), using gender as a covariate. ${ }^{1}$ This ANCOVA was performed to test whether the scale could distinguish between those who reported higher and lower exercise frequencies. The ANCOVA revealed that the participants who exercised three or more times per week $(n=165)$ scored statistically significantly higher on the EAI-R-HU $(M=20.87 \pm S D=5.37)$ than those who exercised less than three times per week $(n=28 ; M=18.32 \pm S D=5.20 ; F[2,250]=6.82, p<.001$; effect size $[$ Cohen's $d]=.48)$.

\subsection{Prevalence of the risk of exercise addiction}

Using the upper $20 \%$ of the scores of the EAI-R-HU as the cutoff point, similarly to the original EAI (Terry et al., 2004), participants were categorized into 'at risk of exercise addiction' (respondents who scored 28.8 or higher), and into 'not at risk' (respondents who scored under 28.8) groups. Based on this classification, the prevalence of the risk of exercise addiction was $5.14 \%$ ( $n=13,2$ men and 11 women) in the current sample. I compared the at-risk and not at-risk groups on their exercise characteristics with the Mann-Whitney independent samples $U$ test to account for the large difference in the sample sizes (Fagerland, 2012; Pett, 2015). The dependent measures were exercise frequency, workout duration, and perceived exercise intensity. The results of the test revealed that the two groups only differed in the average duration of exercise sessions (Table 3).

\subsection{Team and individual exercisers}

Whether the risk of exercise addiction is different between group or team exercisers $(n=122)$ and individual exercisers $(n=131)$ was tested with an ANOVA. The results only approached the level of statistical significance (i.e., team exercisers: $M=20.56 \pm S D=5.41$; individual exercisers: $M=19.44$ $\pm S D=5.42 ; F[1,251]=2.67, p=.10$; effect size [Cohen's $d]=.21$ ) .

\footnotetext{
1 It was deemed necessary because men and women differed on exercise parameter measures (see Table 1).
} 
Table 3. Exercise characteristics of respondents at risk for exercise addiction $(n=13)$ and those who are not at risk of exercise addiction $(n=240)$

\begin{tabular}{|c|c|c|c|c|c|c|c|}
\hline \multirow[t]{2}{*}{ Measures } & \multirow[t]{2}{*}{ Groups } & \multirow[t]{2}{*}{ Mean } & \multirow[t]{2}{*}{ SD } & \multicolumn{2}{|c|}{$\begin{array}{l}\text { 95\% Confidence } \\
\text { Interval }\end{array}$} & \multirow[t]{2}{*}{$Z$} & \multirow[t]{2}{*}{$p$} \\
\hline & & & & Lower & Upper & & \\
\hline \multirow{2}{*}{$\begin{array}{l}\text { Weekly exercise } \\
\text { frequency (days) }\end{array}$} & At risk & 3.69 & 1.25 & 2.94 & 4.43 & \multirow{2}{*}{1.29} & \multirow{2}{*}{.196} \\
\hline & Not at risk & 3.24 & 1.56 & 3.04 & 3.44 & & \\
\hline \multirow{2}{*}{$\begin{array}{l}\text { Duration of an } \\
\text { average workout } \\
\text { (minutes) }\end{array}$} & At risk & 87.69 & 14.81 & 78.74 & 96.64 & \multirow{2}{*}{2.17} & \multirow{2}{*}{.030} \\
\hline & Not at risk & 73.75 & 25.71 & 70.78 & 74.04 & & \\
\hline \multirow{2}{*}{$\begin{array}{l}\text { Perceived intensity of } \\
\text { an average workout } \\
\text { (out of } 10 \text { ) }\end{array}$} & At risk & 6.46 & 2.07 & 5.21 & 7.71 & \multirow{2}{*}{0.79} & \multirow{2}{*}{.430} \\
\hline & Not at risk & 6.08 & 1.65 & 5.87 & 6.29 & & \\
\hline
\end{tabular}

Note: $Z$ value as based on the Mann-Whitney $U$ test.

\subsection{Relationship with age and exercise parameters}

The EAI-R-HU showed weak inverse correlation with age $(r=-.222$, $p<.001)$, weak positive correlation with weekly exercise frequency $(r=.222$, $p<.001)$, with the average duration of exercise sessions $(r=.190, p=.002)$, and with the perceived intensity of an average exercise workout $(r=.265$, $p<.001)$. While a hierarchical linear regression equation emerged to be statistically significant $(F[1,251]=12.96, p<.001)$, two exercise characteristics and age only predicted $13 \%$ of the variance in the risk of exercise addiction $\left(R=.383, R^{2}=.142, R^{2}\right.$ adjusted $\left.=.132\right)$; the average duration of exercise sessions was not a significant predictor in the model. The standardized $\beta$ values for weekly exercise frequency, perceived intensity of exercise workouts, and age were: $.203, .185$, and -.185 , the respective $t$-values and $p$ levels were: $3.32, .001 ; 2.97, .003 ;-3.02, .003$.

\section{Discussion}

The current study's main finding is that the EAI-R-HU has a good model fit similar to or better than the revised English version (Szabo et al., 2019). The latter work is based on a predominantly male sample (243 men and 34 women). In contrast, in the current study, there was a majority of female participants (193) in comparison to the much smaller male representation. 
These results are promising in that the EAI-R, at least the EAI-R-HU, can be used with women too. This gender-relevant finding is important because a cross-cultural evaluation of the EAI showed that gender differences exist in the interpretation of the scale. Further, earlier work has revealed that the EAI factor scores, stemming from five countries, were not comparable because either the scale was not employed in the same way in the five nations, or because its semantic-cognitive interpretation was different among the respondents (Griffiths et al., 2015). Therefore, the psychometric validation of the scale is warranted across different cultures.

\subsection{Gender differences}

In the current study, no gender differences were noted in the EAI-R-HU scores between men and women. These results match the findings reported by Szabo and colleagues (2019), who also found no gender differences in EAI-R absolute scores. The prevalence of the risk of exercise addiction (3.4\% in men and $5.7 \%$ in women) also did not differ statistically significantly between men and women in the current research. These results are in discord with a conclusion stemming from a recent literature review that men tend to be more at risk of exercise addiction than women (Dumitru, Dumitru, \& Maher, 2018). However, the authors noted that these differences are not clear cut and that "...more research is needed to understand the gender differences on the prevalence of exercise addiction" (p. 1738). Further, the review comprised studies using the original EAI, in which a neutral item could have inflated the total score and, hence, the prevalence estimates. The revised EAI may be more reliable in testing gender-related differences in the risk of exercise addiction. By eliminating the neutral midpoint of the scale, the symptoms' relevancy (the agreement half) or irrelevancy (the disagreement half) could help in better segregating subjective experiences, which in turn can yield more accurate results concerning the risk of exercise addiction in men and women.

\subsection{Model fit}

The revised EAI-R-HU exceeded all criteria for fit indices of the theoretical model compared to the EAI-R, in which the TLI was lower than the critical value (Szabo et al., 2019). In the current study, the same result was noted in the male sample, in which the TLI also did not reach the cutoff value. However, there were only 59 men, and in samples under 100, the TLI is sensitive to sample size (Taasoobshirazi \& Wang, 2016). In contrast, all fit indices in the women's sample exceeded the cutoff values, confirming 
excellent model fit in this sub-sample. The fit indices of the EAI-R-HU were slightly above those reported in the population-wide study for the original version of the Hungarian EAI (Mónok et al., 2012). Further, the factor loadings were higher, ranging from .43 to .80 (Figure 1) in contrast to .38 to .72 found in Mónok and colleagues' study (2012).

The factor loadings were lower in the current study than those reported for the EAI-R (Szabo et al., 2019). While factor loadings exceeded .4, the $R^{2}$ of item 2, "Conflicts have arisen between me and my family and/or my partner about the amount of exercise I do," was .18, suggesting that this item has little contribution to the construct validity of the Hungarian version of the EAI-R. This finding may be ascribed to this item's ambiguous nature because conflict can be objective or subjective and, hence, internal or external in all addictions, including behavioral addictions (Meerkerk, Van Den Eijnden, Vermulst, \& Garretsen, 2009). This item had the lowest factor loading (.38 versus .43 in this study) in the validation study of the original version of the Hungarian EAI (Mónok et al., 2012). In a Danish validation study of the EAI, this item's loading was even lower (.32; Lichtenstein, Larsen, Christiansen, Støving, \& Bredahl, 2014b). However, in another research (Lichtenstein, Christiansen, Bilenberg, \& Støving, 2014a), the factor loading of item 2 was .43, identical to that in the present study, which was still the lowest among the six items. The interpretation of this item may be ambiguous only in a language other than English because in the original (Terry et al., 2004) and revised scales (Szabo et al., 2019), EAI item 2 had a factor loading greater than .6. The further cross-cultural validation of the EAI-R will possibly clarify the reason behind the low factor loading of item 2 in the non-English versions of the scale. Apart from this item, the model fit values of the EAI-R-HU were slightly better than those reported for the original translation of the Hungarian EAI (Mónok et al., 2012), which suggests that the revised EAI-R-HU is at least as good as its previous version.

\subsection{Reliability}

The internal reliability of the EAI-R-HU was .71. On the one hand, above .7, the alpha value may be considered acceptable (Taber, 2017). On the other hand, Schmitt (1996) suggested that there is no general cutoff (such as .70) where alpha is acceptable because instruments with low internal reliability can still be useful in some circumstances. The reliability value obtained in the current work is lower than that obtained for the English original EAI (Terry et al., 2004) and the revised EAI (Szabo et al., 2019). Still, it fits within the range reported in a cross-cultural evaluation of the EAI (Griffiths et al., 2015), where it ranged between .61 and .80 . In that investigation, the EAI's 
reliability in two Hungarian samples was .61 and .73, respectively. In the Mónok and colleagues' (2012) population-wide study, the Hungarian EAI's internal reliability was .72, similar to the value obtained in the current work. Therefore, it appears the original and revised versions of the Hungarian EAI have similar internal reliabilities.

\subsection{Discriminant validity based on exercise frequency}

The EAI-R-HU was able to discriminate between those participants who exercise once or twice a week and those who exercise three or more times a week. A similar method was used during the development of the EAI (Terry et al., 2004) and EAI-R (Szabo et al., 2019). The current results agree with their results and support the discriminant validity of the EAI-R-HU.

\subsection{Prevalence}

The prevalence of the risk of exercise addiction was 5.1\% in the current study. This figure is slightly higher than the 3.2\% based on the original EAI reported by Mónok and colleagues (2012) in exercising individuals. Further, this proportion is at the lower end of the spectrum identified by Griffiths and colleagues (2015), ranging from $1.9 \%$ to $42 \%$. It is also lower than that obtained with the EAI-R (11.5\%) by Szabo and colleagues (2019). A conceptual question concerning such prevalence rates was raised by Szabo (2018) in showing that even the athlete scoring high on the various measures of the risk of exercise addiction may not develop psychiatric or dysfunctional problems. It was suggested that there is an overlap with commitment and passion for exercise, which artificially raises the prevalence estimates (Szabo, 2018; Szabo \& Kovacsik, 2019). In light of this conjecture, the more committed (or more heavily involved) exercising people will score higher on the EAI-R, which will manifest as a greater prevalence of the risk of exercise addiction among them. Indeed in the course of the validation of the EAI-R (Szabo et al., 2019), a younger sample aged between 22 and 45 years of predominantly male adults who exercised at least three times a week for at least 30 minutes each time were tested in contrast to the current inquiry in which the participants were aged between 18 and 77 years. Further, most of the current sample was comprised of women, and $88(35 \%)$ only exercised once or twice a week. Prevalence estimates vary in function of exercise characteristics, such as exercise frequency, as shown in the current work, and they do not prognosticate the 
development of psychopathology. Above and beyond these indices, future research should examine the extent to which overtraining syndrome may be related to the risk classification of exercise addiction. Specifically, the sympathetic and parasympathetic overtraining, manifesting in different and opposite symptoms, such as insomnia versus longer sleep time, or retarded versus quick heart rate recovery (Froehlich, 1995), should also examined. However, addressing this question will require the recruitment of participants who exercise with a much greater exercise volume than those studied in the current work. In more heavily involved exercisers the EAI-R-HU scores and associated rate of prevalence could be expected to be higher than in the present work.

\subsection{Team and individual exercisers}

The EAI-R-HU scores did not differ between individuals exercising in a team or alone in the current study. However, the difference approached statistical significance with a small effect size and showed a tendency towards higher scores in team versus individual exercisers. These results agree with previous findings with Spanish, Hungarian, and Danish samples (De La Vega, Parastatidou, Ruíz-Barquín, \& Szabo, 2016; Kovacsik, Soós, De La Vega, Ruíz-Barquín, \& Szabo, 2020; Lichtenstein et al., 2014a,b). Therefore, the results obtained with the EAI-R-HU are identical to those gathered with the original EAI and show that the risk of exercise addiction is unlikely to differ between the team and individual exercisers. However, future studies should examine the risk of exercise addiction in specific forms of team exercises like ballgames or racquetball and individual exercises, such as aerobic (i.e., running, swimming) and anaerobic (i.e., CrossFit, weight training) exercises, to expand the knowledge concerning its sport-specificity.

\subsection{Exercise characteristics and age}

Exercise frequency, duration, and intensity, along with age (inversely), accounted for $13 \%$ of the variance in EAI-R-HU scores. While exercise volume was not (Kovacsik et al., 2018, 2020), the exercise intensity was found to be a significant predictor of the risk of exercise addiction in an earlier study (Kovacsik et al., 2018). Like the current results, another Hungarian study found that the duration of exercise is a predictor of the risk of exercise addiction (Lukács, Sasvári, Varga, \& Mayer, 2019). However, a study by Szabo and Kovacsik (2019) showed that while exercise volume 
seems to predict the risk of exercise addiction, this relationship disappears when the effects of obsessive passion are controlled. Similar to the current results, the study of Szabo and Kovacsik (2019) also showed that age is a significant covariate of the risk of exercise addiction.

When comparing the 13 at-risk for exercise addiction participants to the rest of the sample on their exercise characteristics, only the exercise sessions' duration differentiated the two groups (Table 3). These findings should be interpreted with caution because other factors that were not examined in the current research, such as the level of exercise commitment or passion, could mediate them (Szabo \& Kovacsik, 2019). Indeed, although the exercise characteristics are predictors of the EAI-R-HU scores, other mediating factors, such as passion, could have a more significant influence on this measure (Kovacsik et al., 2020). Therefore, future research in this area should examine the risk of exercise addiction based on the EAI-R scores in conjunction with the other known determinants of this measure.

\subsection{Limitations}

The current study has several limitations. The first is the online examination of an anonymous volunteer sample over which the experimenter has no control. While this practice is now widely adopted in the field of Psychology, especially in the current time of a pandemic, the reliability of the results stemming from online anonymous data should be interpreted with caution. Second, the current study did not perform full psychometric validation of the EAI-R-HU mainly because its items' text was identical to the earlier validated version in both English and Hungarian. Indeed, both the content and concurrent validity of the Hungarian EAI were shown earlier (Mónok et al., 2012). Still, these psychometric measures need to be confirmed for the EAI-R-HU too, and its test-retest reliability should also be established. Third, the current study also included exercisers who only worked out once or twice a week. Although their participation is useful in establishing the discriminant validity of the modified scale, theoretically, these people are extremely unlikely to be at risk of exercise addiction, despite the fact that three individuals at risk of exercise addiction, out of 13, only exercised regularly twice a week. Fourth, although almost identical to that reported in the validation of the EAI-R (i.e., 253 vs. 277), the sample size was small, especially for the men's sample. Last, the form of exercise was not accounted for in the current work. The exercise forms, such as endurance or strength, should also be considered because they appear to be connected to the prevalence of the risk of exercise addiction (Di Lodovico, Poulnais, \& Gorwood, 2019). 


\section{Conclusions}

Modifying the EAI rating scale from five to six points yields a slightly better model fit for the EAI-R-HU in contrast to the earlier validated Hungarian version (Mónok et al., 2012). Its model fit is also somewhat better than that reported for the revised English version (Szabo et al., 2019), but its internal consistency is lower, yet it is similar (.71 vs. .72) to the original Hungarian EAI (Mónok et al., 2012). The model fit is excellent separately for men and women too, even though the former's sample size was too small. The factor loadings of the EAI-R-HU are lower compared to the English version (Szabo et al., 2019) but higher than those of its earlier Hungarian version (Mónok et al., 2012). The EAI-R-HU has good discriminant validity. In contrast to EAI-R that was validated in a predominantly male sample, the current results were obtained in a sample primarily represented by women, which indicates that the revised EAI is useful for studying women exercisers. Overall, these preliminary results indicate that the EAI-R-HU is a valid and reliable instrument.

\section{References}

Allen, I. E., \& Seaman, C. A. (2007). Likert scales and data analyses. Quality Progress, 40(7), 64-65. Retrieved November 2, 2018, from: http:/ / rube.asq.org/quality-progress/2007/07/ statistics/likert-scales-and-data-analyses.html

American Psychiatric Association. (2013). Diagnostic and statistical manual of mental disorders ( $5^{\text {th }}$ ed.). Washington, DC: American Psychiatric Association

Baumgartner, H., \& Homburg, C. (1996). Applications of structural equation modeling in marketing and consumer research: A review. International Journal of Research in Marketing, 13(2), 139-161.

Borg, G. (1985). An introduction to Borg's RPE Scale. Ithaca, NY: Movement Publications.

De La Vega, R., Parastatidou, I. S., Ruíz-Barquín, R., \& Szabo, A. (2016). Exercise addiction in athletes and leisure exercisers: The moderating role of passion. Journal of Behavioral Addictions, 5(2), 325-331.

Demetrovics, Z., \& Kurimay T. (2008). Testedzésfüggóség: a sportolás mint addikció. Psychiatria Hungarica, 23(2), 129-141.

Di Lodovico, L., Poulnais, S., \& Gorwood, P. (2019). Which sports are more at risk of physical exercise addiction: A systematic review. Addictive Behaviors, 93, 257-262.

Dumitru, D., Dumitru, T., \& Maher, A. (2018). A systematic review of exercise addiction: examining gender differences. Journal of Physical Education and Sport, 18(3), 1738-1747.

Egorov, A. Y., \& Szabo, A. (2013). The exercise paradox: An interactional model for a clearer conceptualization of exercise addiction. Journal of Behavioral Addictions, 2(4), 199-208.

Fagerland, M. W. (2012). t-Tests, nonparametric tests, and large studies - a paradox of statistical practice? BMC Medical Research Methodology, 12(1). DOI: 10.1186/1471-2288$12-78$ 
Frey, B. (2018). The SAGE encyclopedia of educational research, measurement, and evaluation (Vols. 1-4). Thousand Oaks, CA: SAGE Publications, Inc. DOI: 10.4135/9781506326139

Froehlich, J. (1995). Overtraining syndrome. In: Heil, J. (Ed.). Psychology of Sport Injury (59-70). Champaign, IL: Human Kinetics

Goodman, L. A. (1961). Snowball sampling. Annals of Mathematical Statistics, 32(1), 148-170.

Griffiths, M. D. (2005). A "components" model of addiction within a biopsychosocial framework. Journal of Substance Use, 10(4), 191-197.

Griffiths, M. D., Szabo, A., \& Terry, R. (2005). The exercise addiction inventory: A quick and easy screening tool for health practitioners. British Journal of Sports Medicine, 39(6), e30-e30. DOI: 10.1136/bjsm.2004.017020

Griffiths, M. D., Urbán, R., Demetrovics, Z., Lichtenstein, M. B., De La Vega, R., Kun, B., et al. (2015). A cross-cultural re-evaluation of the Exercise Addiction Inventory (EAI) in five countries. Sports Medicine - Open, 1(1), 5. DOI: 10.1186/s40798-014-0005-5

Hausenblas, H. A., \& Downs, D. S. (2002). How much is too much? The development and validation of the Exercise Dependence Scale. Psychology and Health, 17(4), 387-404.

Hu, L., \& Bentler, P. M. (1999). Cutoff criteria for fit indexes in covariance structure analysis: Conventional criteria versus new alternatives. Structural Equation Modeling: A Multidisciplinary Journal, 6(1), 1-55.

Kline, R. B. (2015). Principles and practice of structural equation modeling. New York, NY: Guilford Publications

Kovacsik, R., Griffiths, M. D., Pontes, H. M., Soós, I., De La Vega, R., Ruíz-Barquín, R., et al. (2018). The role of passion in exercise addiction, exercise volume, and exercise intensity in long-term exercisers. International Journal of Mental Health and Addiction, 17(6), 13891400.

Kovacsik, R., Soós, I., De La Vega, R., Ruíz-Barquín, R., \& Szabo, A. (2020). Passion and exercise addiction: Healthier profiles in team than in individual sports. International Journal of Sport and Exercise Psychology, 18(2), 176-186.

Lichtenstein, M. B., Christiansen, E., Bilenberg, N., \& Støving, R. K. (2014a). Validation of the exercise addiction inventory in a Danish sport context. Scandinavian Journal of Medicine and Science in Sports, 24(2), 447-453.

Lichtenstein, M. B., Larsen, K. S., Christiansen, E., Støving, R. K., \& Bredahl, T. V. G. (2014b). Exercise addiction in team sport and individual sport: Prevalences and validation of the exercise addiction inventory. Addiction Research and Theory, 22(5), 431-437.

Lukács, A., Sasvári, P., Varga, B., \& Mayer, K. (2019). Exercise addiction and its related factors in amateur runners. Journal of Behavioral Addictions, 8(2), 343-349.

Meerkerk, G. J., Van Den Eijnden, R. J., Vermulst, A. A., \& Garretsen, H. F. (2009). The compulsive internet use scale (CIUS): some psychometric properties. Cyberpsychology and Behavior, 12(1), 1-6. DOI: 10.5505/kpd.2020.81489

Mónok, K., Berczik, K., Urbán, R., Szabo, A., Griffiths, M. D., Farkas, J., et al. (2012). Psychometric properties and concurrent validity of two exercise addiction measures: A population wide study. Psychology of Sport and Exercise, 13(6), 739-746.

Qualtrics (2017). Survey research suite: Research core ${ }^{\mathrm{TM}}$. Provo, Utah, USA. Retrieved November 2, 2018, from: http:/ / www.qualtrics.com

Pett, M. A. (2015). Nonparametric statistics for health care research: Statistics for small samples and unusual distributions. Washington, DC: Sage

Schmitt, N. (1996). Uses and abuses of coefficient alpha. Psychological Assessment, 8(4), 350-353.

Shi, D., Lee, T., \& Maydeu-Olivares, A. (2019). Understanding the model size effect on SEM fit indices. Educational and Psychological Measurement, 79(2), 310-334. 
Szabo, A. (2010). Addiction to exercise: A symptom or a disorder? Hauppauge, NY: Nova Science Publishers, Incorporated

Szabo, A. (2018). Addiction, passion, or confusion? New theoretical insights on exercise addiction research from the case study of a female body builder. Europe's Journal of Psychology, 14(2), 296-316.

Szabo, A., Griffiths, M. D., De La Vega Marcos, R., Mervó, B., \& Demetrovics, Z. (2015). Methodological and conceptual limitations in exercise addiction research. Yale Journal of Biology and Medicine, 88(3), 303-308.

Szabo, A., \& Kovacsik, R. (2019). When passion appears, exercise addiction disappears. Swiss Journal of Psychology, 78(3-4), 137-142.

Szabo, A., Pinto, A., Griffiths, M. D., Kovacsik, R., \& Demetrovics, Z. (2019). The psychometric evaluation of the Revised Exercise Addiction Inventory: Improved psychometric properties by changing item response rating. Journal of Behavioral Addictions, 8(1), 157-161.

Taasoobshirazi, G., \& Wang, S. (2016). The performance of the SRMR, RMSEA, CFI, and TLI: An examination of sample size, path size, and degrees of freedom. Journal of Applied Quantitative Methods, 11(3), 31-39.

Taber, K. S. (2017). The use of Cronbach's alpha when developing and reporting research instruments in science education. Research in Science Education, 48(6), 1273-1296.

Terry, A., Szabo, A., \& Griffiths, M. (2004). The exercise addiction inventory: A new brief screening tool. Addiction Research and Theory, 12(5), 489-499.

\section{Conflict of interest}

The author has no conflict of interest to declare. 


\section{APPENDIX: \\ Revised Hungarian Exercise Addiction Inventory ${ }^{2}$}

Instruction: Please indicate the extent to which you disagree or agree with the following statements. / Kérem jelölje meg, hogy mennyire ért egyet az alábbi állításokkal!

(1) Strongly disagree / egyáltalán nem értek egyet

(2) Disagree / nem értek egyet

(3) Slightly disagree / inkább nem értek egyet

(4) Slightly agree / inkább egyetértek

(5) Agree / egyetértek

(6) Strongly agree/ teljes mértékben egyetértek

\begin{tabular}{|c|c|c|c|c|c|c|}
\hline $\begin{array}{l}\text { 1. Exercise is the most important thing in my life. / } \\
\text { A testedzés a legfontosabb dolog az életemben. }\end{array}$ & 1 & 2 & 3 & 4 & 5 & 6 \\
\hline $\begin{array}{l}\text { 2. Conflicts have arisen between me and my family and/or } \\
\text { my partner about the amount of exercise I do. / Konflik- } \\
\text { tusok adódnak köztem és a családom és /vagy partnerem } \\
\text { között amiatt, hogy mennyit edzek. }\end{array}$ & 1 & 2 & 3 & 4 & 5 & 6 \\
\hline $\begin{array}{l}\text { 3. I use exercise as a way of changing my mood } \\
\text { (e.g. to get a buzz, to escape, etc.) / A testedzést arra } \\
\text { használom, hogy a hangulatomon változtassak } \\
\text { (pl. hogy kellemesebben érezzem magam, vagy hogy } \\
\text { ne kelljen a problémáimmal foglalkoznom). }\end{array}$ & 1 & 2 & 3 & 4 & 5 & 6 \\
\hline $\begin{array}{l}\text { 4. Over time I have increased the amount of exercise } \\
\text { I do in a day. / Az elmúlt idöszak során növeltem } \\
\text { a napi edzés-mennyiségemet. }\end{array}$ & 1 & 2 & 3 & 4 & 5 & 6 \\
\hline $\begin{array}{l}\text { 5. If I have to miss an exercise session, I feel moody } \\
\text { and irritable. / Ha ki kell hagynom egy edzést, } \\
\text { rosszkedvú és ideges leszek. }\end{array}$ & 1 & 2 & 3 & 4 & 5 & 6 \\
\hline $\begin{array}{l}\text { 6. If I cut down the amount of exercise I do, and then start } \\
\text { again, I always end up exercising as often } \\
\text { as I did before. / Ha lecsökkentem a szokásos } \\
\text { edzésmennyiségemet, akkor amikor újra elkezdem az } \\
\text { edzést, addig folytatom, amíg az eredeti } \\
\text { mennyiséget el nem érem. }\end{array}$ & 1 & 2 & 3 & 4 & 3 & 6 \\
\hline
\end{tabular}

\section{Scoring:}

A total score above 28.8 (scores ranging from 19 to 36) reflect the risk of exercise addiction.

2 The Hungarian text is in bold italics. 


\title{
A módosított Testedzésfüggóség Kérdôív (EAI-R-HU) magyar változatának modellillesztése és megbízhatósága
}

\author{
SZABÓ ATTILA
}

\begin{abstract}
A Testedzésfüggőség Kérdőív (EAI) egy rövid, validált eszköz, amelyet a testedzésfüggőség kockázatának felmérésére használnak. Az angol nyelvú módosított változatát (EAI-R) nemrégiben egy többségében férfiakból álló mintán validálták. Jelen kutatás a magyar változat (EAI-R-HU) egyfaktoros elméleti struktúrájának illeszkedését, validitását, és a kérdőív belső megbízhatóságát vizsgálta. A hozzáférhetőségi mintavétellel zajló adatgyújtés online történt. Rendszeresen edző önkéntesek $(n=253)$ kitöltötték a módosított EAI-t (EAI-R-HU) és megválaszolták a demográfiai kérdéseket. A megerősító faktoranalízis jó modellillesztést mutatott, a skála belső megbízhatósága (Cronbach- $\alpha$ ) pedig 0,71 volt. Az EAI-R-HU pontszámok felső 20\%-át figyelembe véve, a jelen minta 5,14\%-a volt feltételezhetően a testedzésfüggőség kockázatának kitéve. A csoportban edzők nem különböztek az egyéni edzést végzőktől a testedzésfüggőség kockázatát illetően. Az életkor és a testmozgás egyes jellemzői gyengén, de statisztikailag szignifikánsan prognosztizálták a testedzésfüggőség kockázatát. Az eredmények alapján az EAI-R-HU jó modellalkalmazással rendelkezik és a belső megbízhatósága elfogadható. Ezek a megállapítások kiegészítik az angol EAI-R változatát, amely nagyrészt $(87,7 \%)$ férfi minta alapján jött létre, szemben a jelen kutatással, amely elsősorban nói résztvevőkön alapszik (76,7\%). Bár létezhetnek kulturális különbségek, a jelenlegi eredmények ösztönzik az EAI-R alkalmazását a nőknél is és az EAI-R-HU felhasználását magyar kutatásokban.
\end{abstract}

Kulcsszavak: viselkedési addikció, testedzés, testedzésfüggőség, kérdőívfejlesztés, pszichometria

This is an open-access article distributed under the terms of the Creative Commons Attribution 4.0 International License (https://creativecommons.org/licenses/by/4.0/), which permits unrestricted use, distribution, and reproduction in any medium, provided the original author and source are credited, a link to the CC License is provided, and changes - if any - are indicated. (SID_1) 